\title{
Quality of life of the population resident at the radioactively contaminated area in Zhytomyr Region
}

\author{
L. D. Romanchuk ${ }^{1}$, L. O. Herasymchuk ${ }^{1}$, S. P. Kovalyova ${ }^{2}$, Yu. V. Kovalchuk ${ }^{1}$, O. V. \\ Lopatyuk $^{1}$
}

\author{
${ }^{1}$ Zhytomyr National Agroecological University, Zhytomyr, Ukraine \\ ${ }^{2}$ Zhytomyr Branch State Institution, Soils Protection Institute of Ukraine, Zhytomyr, Ukraine \\ E-mail: Gerasim4uk@ukr.net
}

Received: 11.11.2019. Accepted: 05.12.2019

\begin{abstract}
The article provides the assessment of the quality of life of the population resident at the radioactively contaminated areas of the Yemilchyno, Malyn, Korosten, Narodychi, Olevsk, Luhyny and Ovruch raions of the Zhytomyr region. The basis for the study and assessment of the quality of life of the population of radioactively contaminated administrative raions of the Zhytomyr region were the statistical data of the Main Directorate of Statistics in Zhytomyr Region, the Health Directorate of Zhytomyr Region State Administration, as well as our own results of a sociological survey. It was established that for the period between 2002 and 2018 , the population of radioactively contaminated areas decreased by $24.7 \%$ (maximum values are representative of Malyn and Korosten raions). Natural population decline rates in rural settlements exceeded the corresponding values for urban settlements from 1.4 (Malyn raion) to 13 times (Olevsk raion). There is also the aging of the population, the largest share of the elderly (65 years old and older) $-21.7 \%$ and $20.8 \%$ are resident in the Korosten and Narodychi raions. The values of birth rates (7.5 (Ovruch raion)-13 (Olevsk raion) per 1,000 of present population) did not have a positive effect on the demographic situation as a whole because of the high mortality rate exceeding the birth rate by 1.1 (Olevsk raion) -2.9 times (Malyn raion). The main causes of death are diseases of the circulatory system (75.4\%), cancer (10\%) and external factors $(7.3 \%)$. It was noted that there is a deterioration of the health of the local population; they pointed out that diseases related to the ChNPP accident include cardiovascular diseases, diseases of the circulatory, nervous and endocrine systems, diseases of bones and joints, headaches. The living conditions of the population resident at the radioactively contaminated areas of Zhytomyr region are unsatisfactory, which is confirmed by both objective data and subjective assessments of the residents themselves. The housing stock is outdated and it needs renovation. In order to improve the quality of life of the population of radioactively contaminated territories in the Zhytomyr region, it is necessary to reform the state policy, to provide financial support for their revival and creation of normal living and reproduction conditions for the population.
\end{abstract}

Key words: Radioactively contaminated area in Zhytomyr region; Quality of life of the population; Demographic trends; Medical state; Living conditions

\section{Introduction}

The quality of life of the population is one of the most important social categories that are the basis for the concepts of economic growth and social development (Romanchuk, 2015). Today, improvement of the quality of life is a common idea and is considered a priority by the authorities at all levels; and it is also an indicator of the effectiveness of state policy.

According to the Quality of Life Index (Numbeo, 2019), Ukraine ranks 65th among 77 countries in the world and 34th among the European countries, despite the fact that at the legislative level, the Sustainable Development Strategy "Ukraine 2020" approved by the Presidential Decree as of January 12, 2015, No. 5/2015 defines improvement of the living standards as a component of the vector of state development. Quality of life is a very broad concept that is related to the general well-being in society, it can be defined in many ways, which makes it difficult to measure (Keles, 2012, Theofilou, 2013).

The problem of quality of life was reflected in the works of domestic and foreign scholars, because it is the human factor that is decisive in the development of any state. Thus, the question of assessing the quality of life of the population of Pakistan was covered by Lodhi et al. (2019), of southeastern Poland by Ćwirlej-Sozańska et al. (2018), of Germany by Huber et al. (2017), of the capital of Slovenia, Ljubljana, by Tiran (2016), of the Dutch by Gobbens \& van Assen (2018), of Romania and Lithuania by Streimikiene (2014), of Italy by Bonatti et al. (2017), Cecchini et al. (2019).

The factors affecting the decline in quality of life include the environmental component (Streimikiene, 2014; Gobbens \& van Assen, 2018), aging of the population (Ćwirlej-Sozańska et al., 2018; Lodhi et al., 2019), increasing number of chronic diseases (ĆwirlejSozańska, 2018), rural residence (Lodhi et al., 2019), quality of living conditions (Tiran, 2016; Li et al., 2017).

The issue of assessing the quality of life in territories exposed to radioactive contamination remained unaddressed.

During the 33-years' period after the Chernobyl accident, there were significant changes in the pollution levels of environment, food, as well as in the socioeconomic development of radioactively contaminated territories. However, there are no positive trends in the 
quality of life of rural residents. During the period, all efforts of the state were directed at countermeasures and social protection of the population, yet due regard was not given to the development of qualitative characteristics of living conditions of the rural population resident at the radioactively contaminated areas in Zhytomyr region. Based on the above stated, the issue of assessing the quality of life in the radioactively contaminated territories of Ukraine, namely in the Zhytomyr region, is extremely relevant and needs comprehensive research. The purpose of the research was to evaluate the quality of life of the population resident at the radioactively contaminated areas in Zhytomyr region.

\section{Materials and Methods}

The quality of life of the population resident at the radioactively contaminated administrative raions of the Zhytomyr region was assessed on the basis of statistical data from the Main Directorate of Statistics in Zhytomyr Region, the Health Directorate of Zhytomyr Region State Administration, as well as our own sociological survey among local residents.

The quality of life of the population resident at the radioactively contaminated territories in the Zhytomyr region was assessed using the following components: 1) demography (size, natural decline, gender structure, distribution of population, birth and mortality rates, causes of death); 2) medical state (morbidity and incidence rates of the population, main diseases and their manifestations); 3) socioeconomic living environment (living conditions).

\section{Result and Discussion}

The processes of functioning of households in the radioactively contaminated territories occur under the long-term factor of radioactive contamination, which causes certain features of forming the quality of life of the population in the region. Keles (2012) and Streimikiene (2014) confirmed that it is the environmental component that is one of the most important components of quality of life. Pereira et al. (2015) argued that the environment should be considered as an object that promotes not only longevity but also health and quality of life. Gobbens \& van Assen (2018) emphasize that it is the link between quality of life and the environment that has been an important subject matter over the last few decades.

Along with the socioeconomic development parameters, the ecological state of the territory has a direct impact on demographic processes. These are the demographic indicators (size, birth rates, mortality rates, natural population increase/decline) that indicate positive or negative trends in the quality of life in a particular area (Herasymchuk et al., 2019).

Between 2002 and 2018, the population resident at the radioactively contaminated areas of the Zhytomyr region decreased by $24.7 \%$ (or by 81.3 thousand people), while in the territory of the Zhytomyr region as a whole by $11.3 \%$. The dynamics of change in size of the population in the context of radioactively contaminated areas in Zhytomyr region is presented in Figure 1.

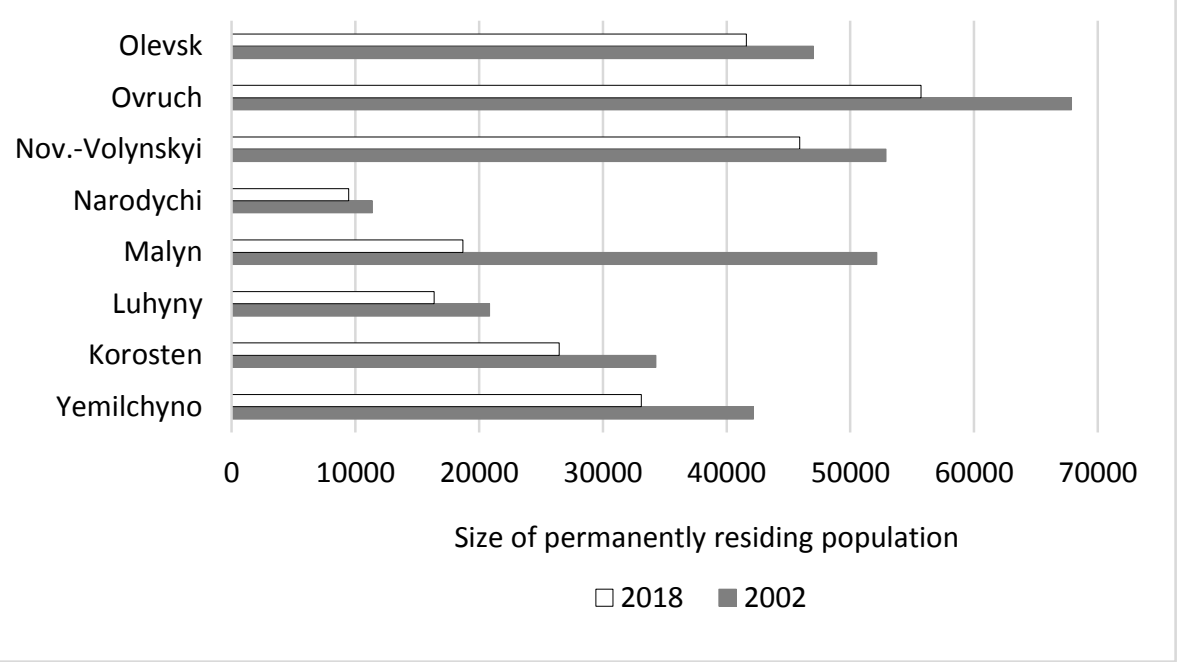

Figure 1. Changes in the size of permanently settled population in the context of radioactively contaminated areas in Zhytomyr region in 2018 compared to 2002.

In the context of administrative raions of the region, the maximum values of the total population decline were representative of the Malyn raion, where the number decreased by $64.2 \%$ (or 33.5 thousand people). Population decline of $21.5-22.9 \%$ occurred in Yemilchyno (by 9.0 thousand people), Luhyny (by 4.5 thousand people) and Korosten raions (by 7.8 thousand people). In Ovruch and Narodychi raions, which suffered the most from the Chernobyl accident, the size of population decreased by $17.9 \%$ and $17 \%$ respectively. The lowest indicators of population decline were recorded for Novograd-Volynskyi (by $13.2 \%$ or 6.9 thousand people) and Olevsk raions (by $11.5 \%$ or 5.4 thousand people) (Figure 1 ).

It should be noted that Ukraine is in the list of countries where the largest population decline will occur between 2019 and 2015. Thus, according to UN forecasts ("medium variant"), the size of population in Ukraine will have decreased to 40882 thousand people by 2030 , to 35219 thousand people by 2021, to 24413 thousand people by 2100 ("high variant" - 37484 thousand people, "low variant" -14897 thousand people). The population decline is associated with the persistent low birth rates and high emigration rates. Along with the population decline, there is an unprecedented aging (United Nations, 2019).

It should be pointed out that the sharp population decline is also a serious challenge for all authorities at all levels.

It was established that the values of the crude rates of natural population decline in Korosten and Malyn raions exceeded the corresponding indicator in the region by $1.9-2.2$ times. It should be noted that in all raions of Zhytomyr region affected by the Chernobyl accident, the crude rates of natural population decline in rural settlements exceeded the corresponding values for urban settlements from 1.4 (Malyn raion) to 13 times (Olevsk raion) (Figure 2). 


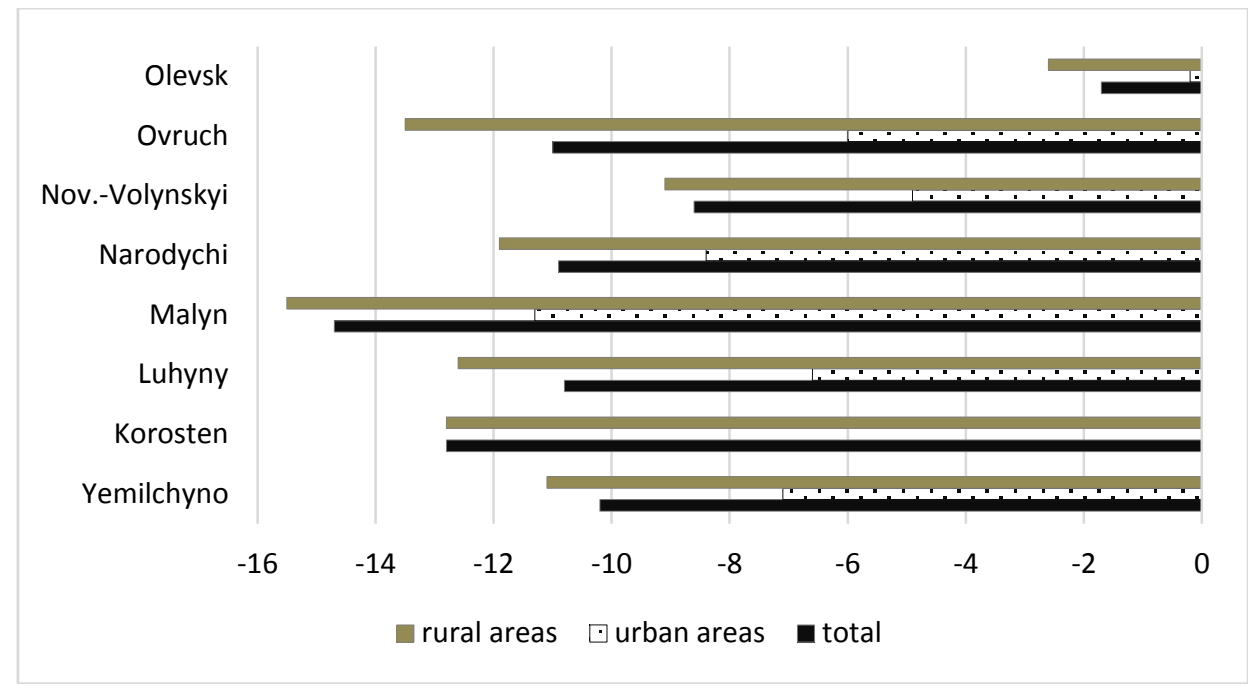

Figure 2. Natural population decline in radioactively contaminated areas in Zhytomyr region in 2018 (per 1,000 of present population).

The obtained data is reflected in the works of Kuczabski \& Michalski (2013), Chornyi \& Shevchuk (2013), Kohler et al. (2017), Johnson \& Lichter (2019). In particular, the latter point out that the depopulation of rural settlements creates a threat to national security, the conservation of the gene pool of the Ukrainian people, and the development of labor potential in general. According to Ubarevičienè \& van Ham (2017), these are the demographic differences between regions that lead to their unbalanced spatial development. The gender structure of the population is uneven across the studied raions of the Zhytomyr region: per 1,000 women, there are between 850 (Narodychi raion) and 916 men (Olevsk raion) (Figure 3).

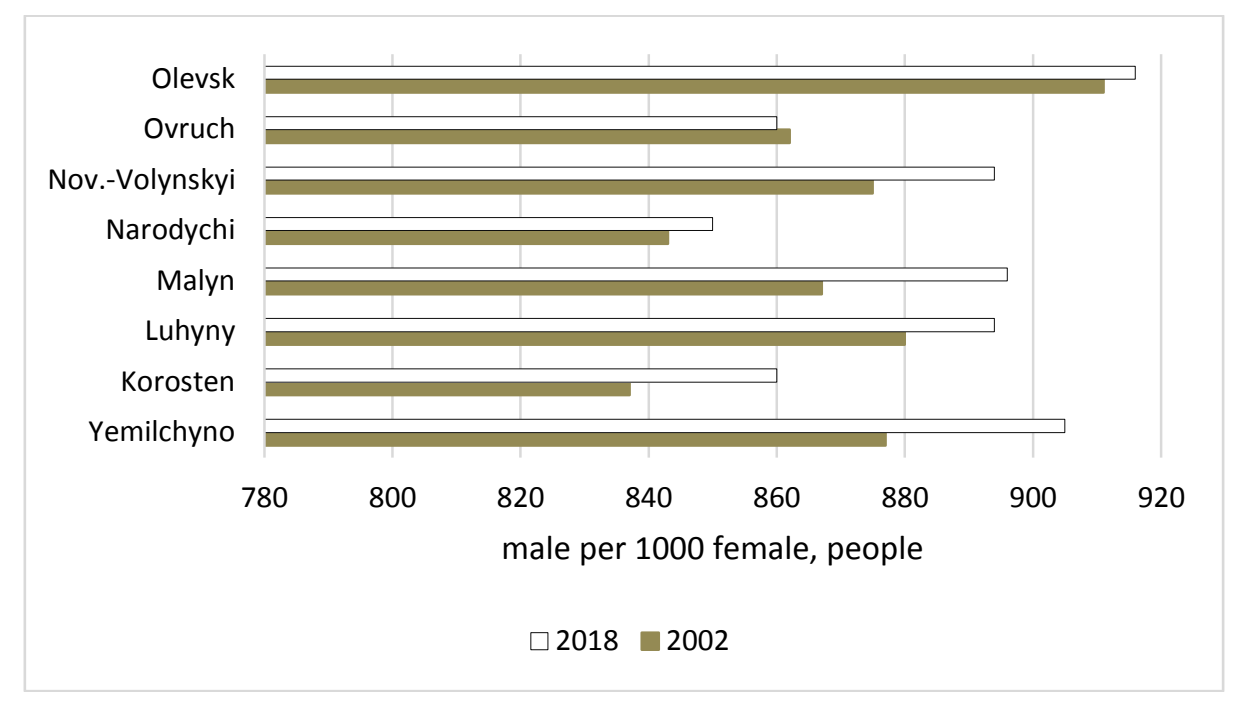

Figure 3. Gender structure of the population in radioactively contaminated areas in Zhytomyr region.

It is known that the process of aging of the population, i.e. the growing proportion of old people in the total population, began in the territory of Ukraine in the middle of the twentieth century. The territories of radioactively contaminated areas in the Zhytomyr region are not an exception. The largest share of the elderly (65 years old and older) $-21.7 \%$ and $20.8 \%-$ live in the Korosten and Narodychi raions, as for children and able-bodied population - $20.6 \%$ and $66.9 \%$-in the Olevsk raion (with the smallest share of the elderly - 12.5\%) (Figure 4). This structure is quite logical, given the above data. The aging of the population characterized by a decline in the proportion of children and an increase in the proportion of older people directly affects the level of demographic burden. Research by Vogelsang \& Raymo (2014) showed that differences in the compisition of population play an important role in forming the observed relationships between the age structure at the local level and individual health. Cecchini et al. (2019) note that the size of the population and its structure affect the regional resilience and are an important driving force of land use, while demographic trends make it possible to identify socioeconomic resilience and to formulate strategies aimed at encouraging faster recovery of local systems from external shocks. As noted by Kohler et al. (2017), depopulation and aging have consequences beyond the scope of demography, since the aging will require better health and social care, which will increase costs, and tax revenues will decrease, just like local capacities for innovation and development, and depopulation will lead to a decline in effective delivery of services. 


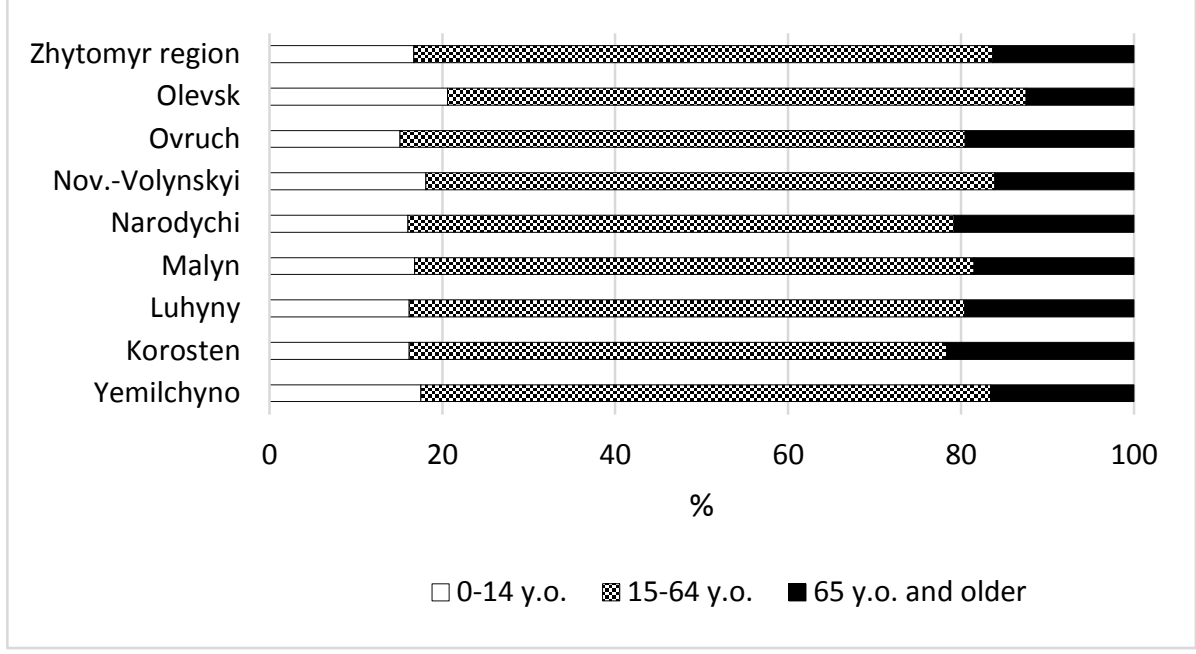

Figure 4. Distribution of permanently settled population resident at the radioactively contaminated areas in Zhytomyr region as of January 01, 2018.

The main indicator reflecting the reproduction of population is birth rate. Birth rates of the population in the context of the radioactively contaminated areas in Zhytomyr region were ranged from 7.5 (Ovruch raion) to 13 (Olevsk raion) per 1,000 of of present population with the average value in the region amounting to 9.4 (Figure 5).

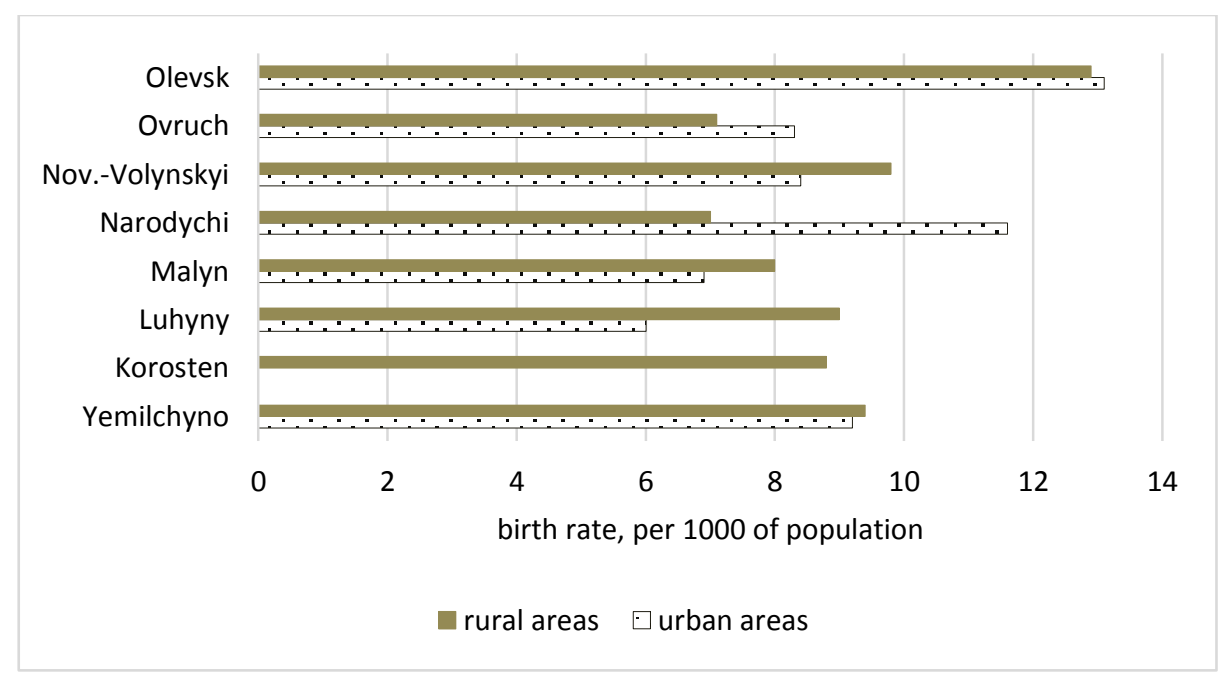

Figure 5. Crude birth rate of the population resident at the radioactively contaminated areas in Zhytomyr region as of January 01 , 2018.

However, the presented values of birth rates did not have a positive effect on the demographic situation as a whole because of the high mortality rate. The values of mortality rates exceeded the corresponding birth rates by 1.1 (Olevsk raion) -2.9 times (Malyn raion). The excess of mortality rates over births rates within $2.1-2.5$ times was observed in the territory of Yemilchyno, Luhyny, Narodychi, Ovruch and Korosten raions (Figure 6). It was established that in these raions, reproduction of the population is closely interrelated with the socioeconomic features of the territory development.

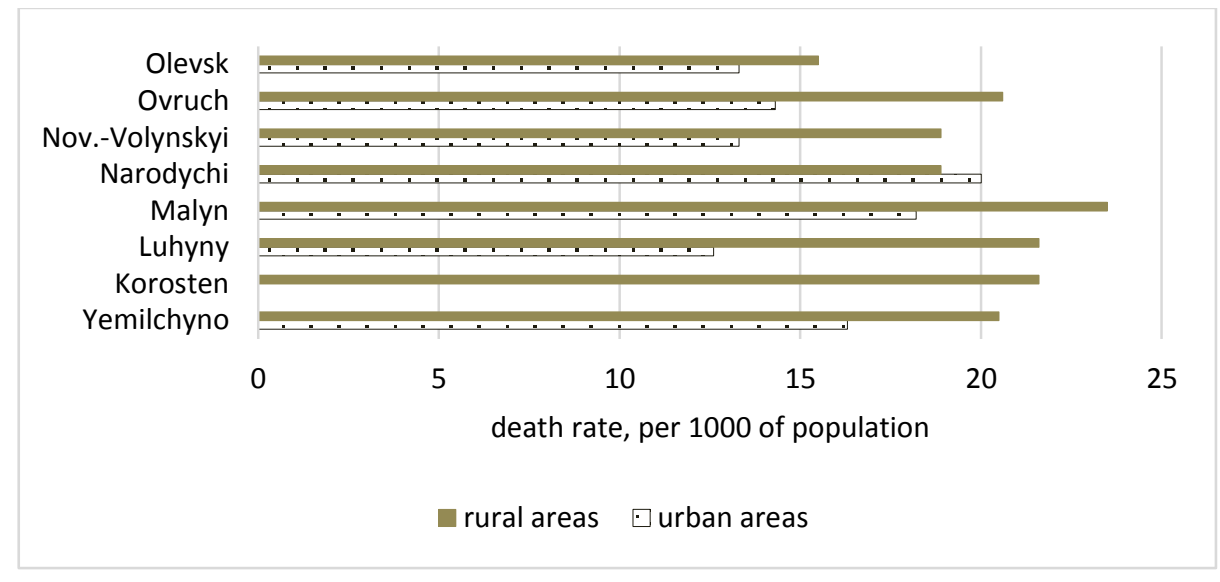

Figure 6. Crude death rate of the population resident at the radioactively contaminated areas in Zhytomyr region as of January 01 , 2018. 
The main causes of death are diseases of the circulatory system (75.4\%), cancer (10\%) and external factors (7.3\%) (Figure 7). The values of mortality rates in the context of the radioactively contaminated areas in the region are presented in more detail in Figure 8 .

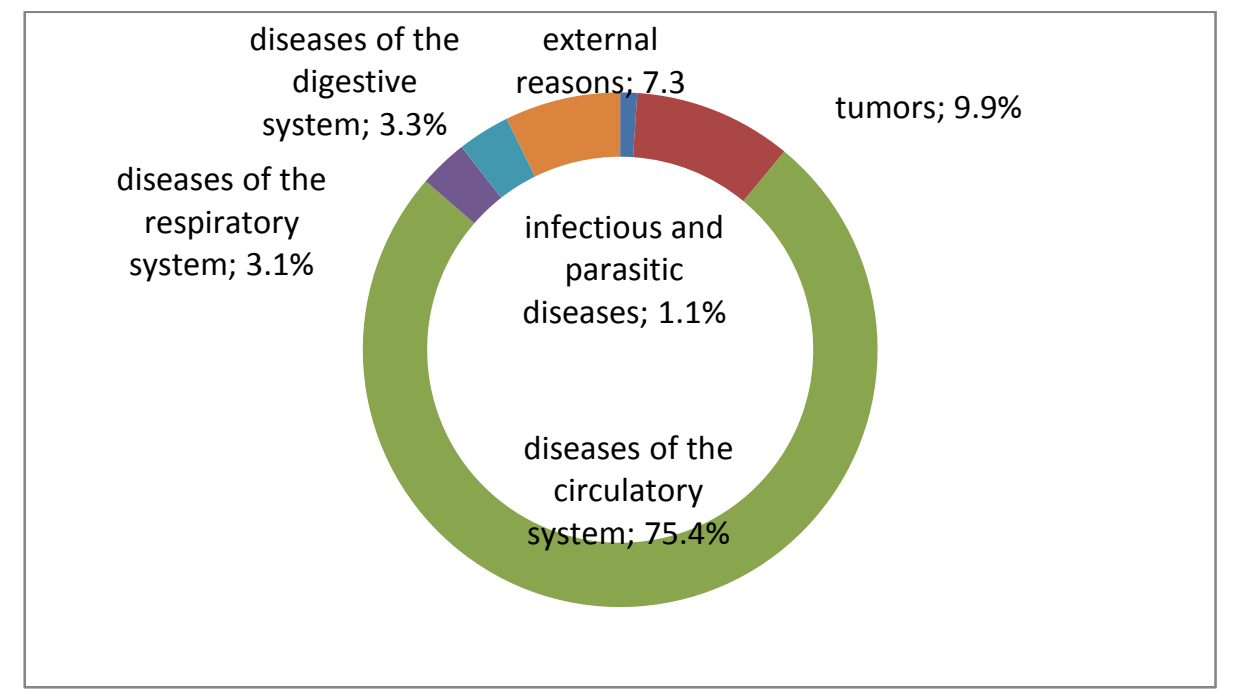

Figure 7. Death rates by reasons.

Maximum values of mortality rates were recorded due to:

- $\quad$ Some infectious and parasitic diseases, as well as diseases of the circulatory system - in the territory of Malyn raion - 37.5 та 1613.6 per 100 thousand of present population;

- Tumors, diseases of the digestive system as well as external factors - in the territory of Narodychi raion - 232.2, 105.6 and 158.3 per 100 thousand of present population, respectively;

- Diseases of the respiratory system - in the territory of Olevsk - 118.1 per 100 thousand of present population (Figure 8).

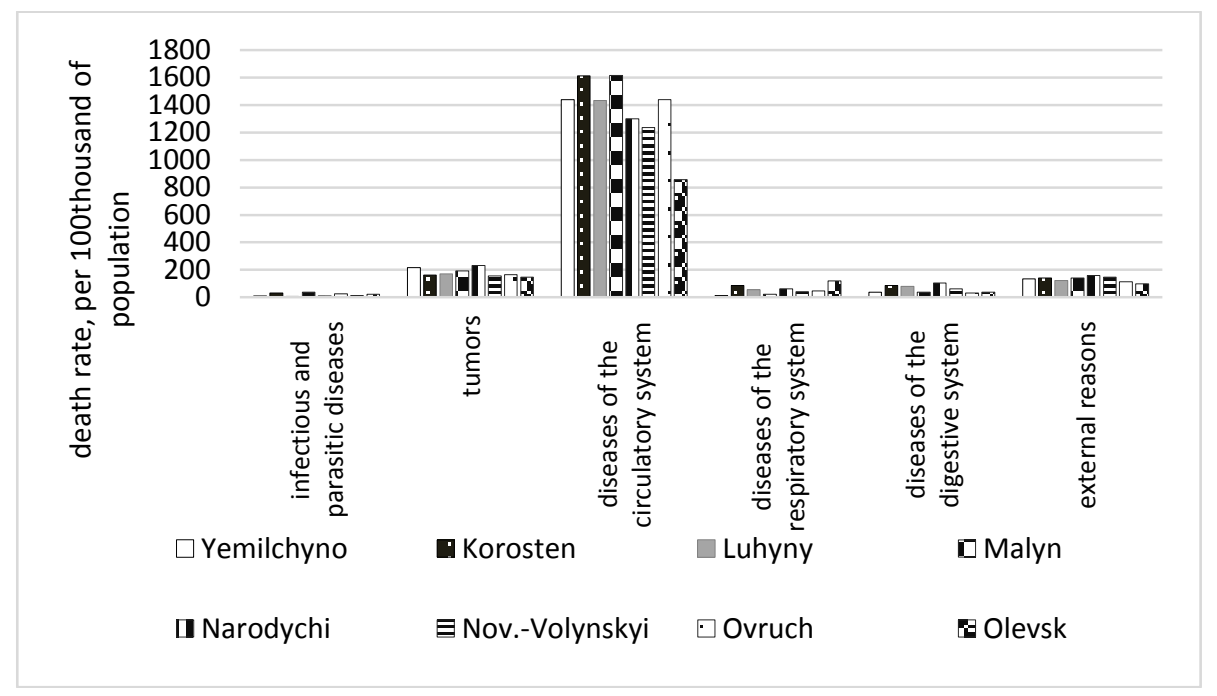

Figure 8. Death rates of the population by main reasons in the context of radioactively contaminated areas in Zhytomyr region, 2017.

Apart from the negative demographic trends in the territories affected by the ChNPP accident, there is also a deterioration in the health of the locals. Yeroshkina \& Derevyanko (2018) highlight the demographic crisis, the main signs of which are unfavorable changes not only in the size but also in the medical state of population, which is manifested in a decrease in life expectancy, deterioration of health of children and adolescents, increase in birth defects in newborns, high death rates from diseases in the territory of Ukraine. At the same time, a sharp decline in the qualitz of life of population is seen in the protracted economic crisis, the ChNPP accident, and the fact that the country is currently in a state of hybrid war. Thus, the morbidity rates of diseases exceed the corresponding indicator in the region in Luhyny and Ovruch raions, and the incidence rates of the population during 2017 was within its limits (Figure 9). 


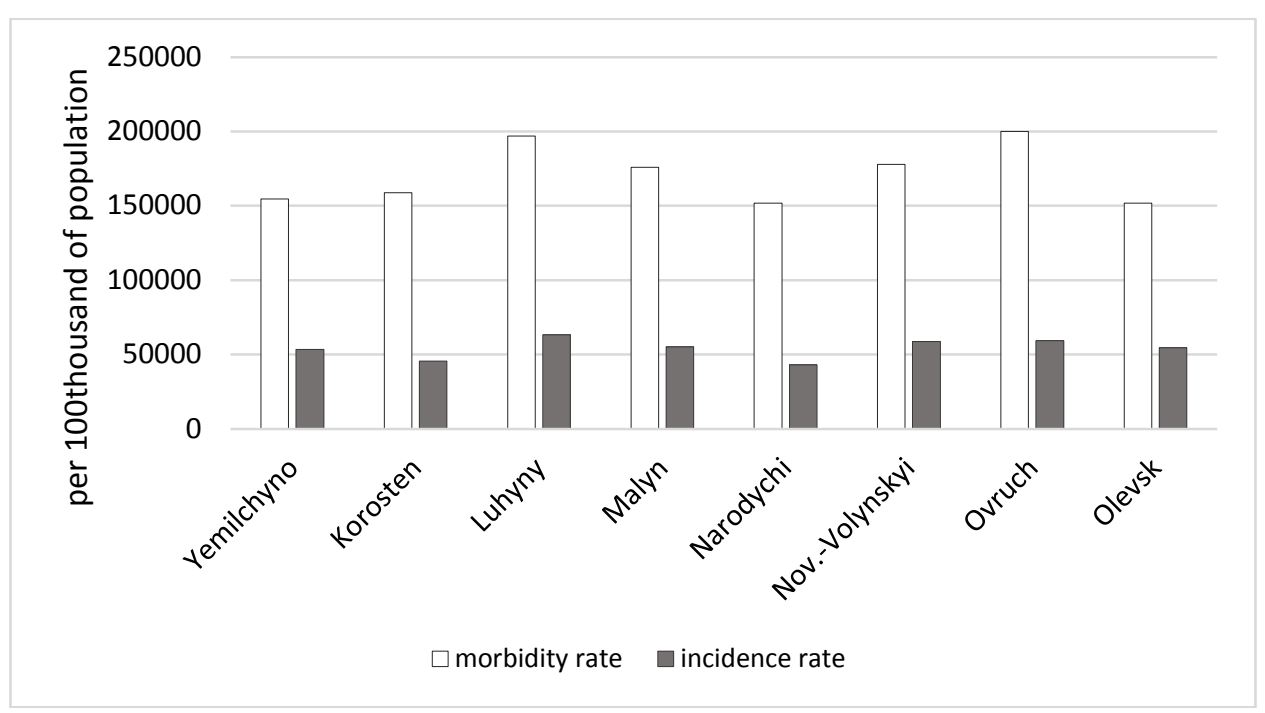

Figure 9. Morbidity and incidence rates of the population resident at the radioactively contaminated areas in Zhytomyr region.

It was found out that the most common diseases among residents of radioactively contaminated areas include cardiovascular diseases and diseases of the circulatory system, diseases of ENT-organs, headaches, bone and joint diseases. $14.7 \%$ of people in the survey indicated that they had chronic diseases. According to the locals' opinion, the ChNPP accident is associated with cardiovascular diseases, diseases of the circulatory, nervous and endocrine systems, diseases of bones and joints, headaches (Figure 10).

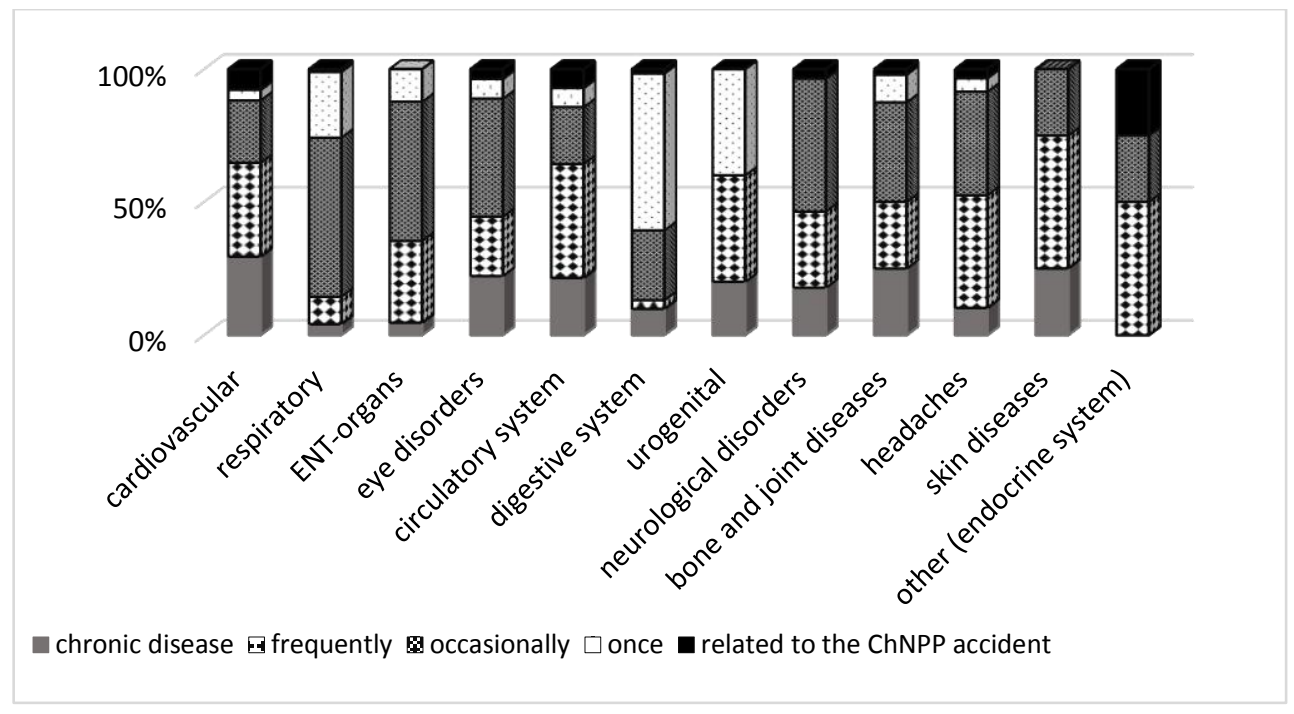

Figure 10. Main diseases of the population resident at the radioactively contaminated areas and their manifestations.

Demographic trends and medical state of the population are directly affected by the socioeconomic conditions of the living environment. The dynamics of Per capita housing supply in the radioactively contaminated areas in the Zhytomyr region during $2000-2017$ is presented in Figure 11.

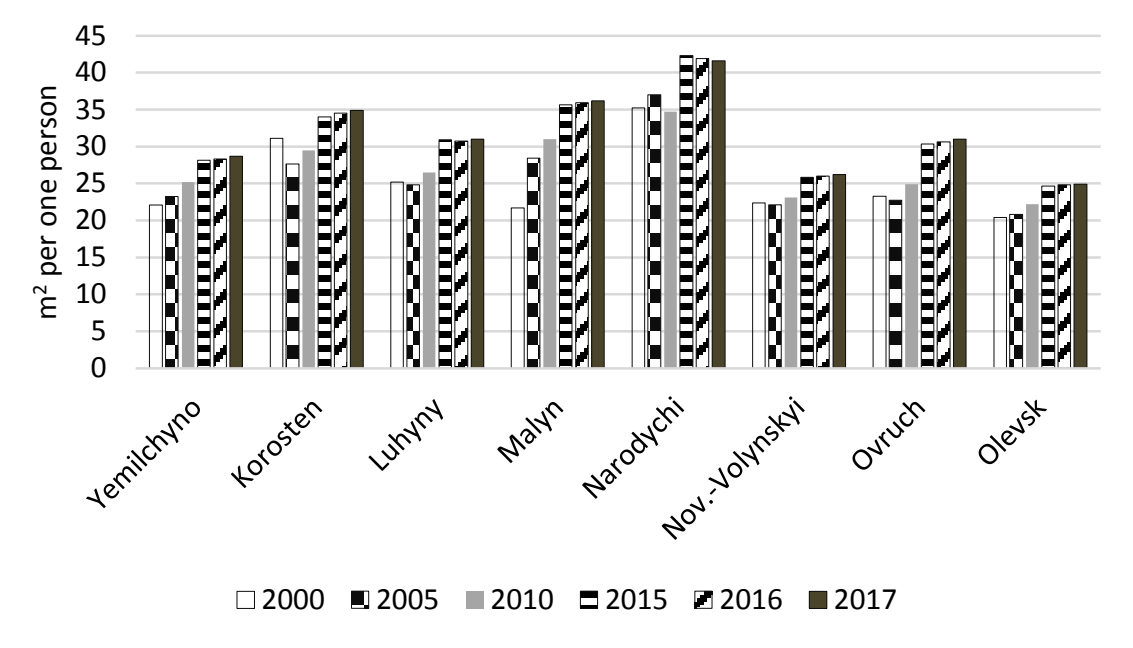

Figure 11. Per capita housing supply in radioactively contaminated areas in Zhytomyr region during 2000-2017. 
Despite the positive dynamics in terms of housing supply of the population resident at the territories affected by the ChNPP disaster (Figure 11), there is a dilapidated and emergency housing stock, and 61.7 (Olevsk raion) - 96.3\% (Luhyny raion) of residential buildings had been built before 1970. It is also worrying that there are a small number of residential buildings located in rural areas of the radioactively contaminated areas in the Zhytomyr region, which are provided with the centralized heating, water supply, wastewater disposal and natural gas supply (Figure 12).

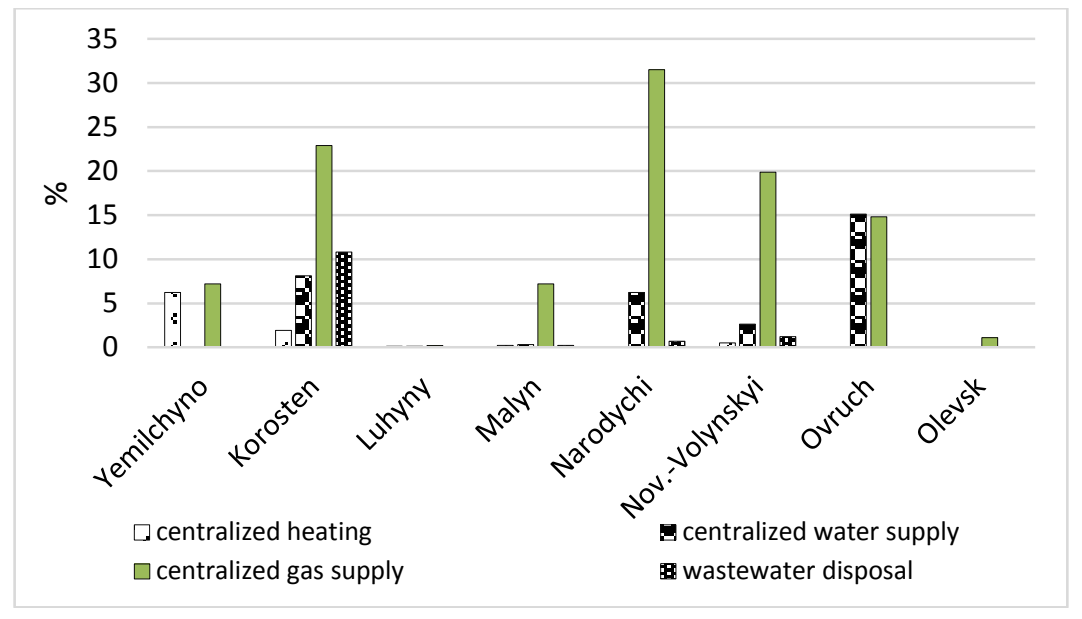

Figure 12. Assessment of residential properties in radioactively contaminated areas in Zhytomyr region as of January $01,2018$.

The conducted sociological survey among residents of radioactively contaminated areas in the Zhytomyr region, it was found that in $37 \%$ of cases, major repairs were carried out in the 1980 s, in $19 \%$ in the 1990 s, in $18 \%$ until 1980 , in $11 \%$ between 2001 and 2010 , in $14 \%$ since 2011 to this day. Thus, the living conditions of the population resident at the radioactively contaminated areas of Zhytomyr region are unsatisfactory, which is confirmed by both objective data and subjective assessments of the residents themselves It should be noted that the obtained results need further research, since a more complete and reliable picture will be obtained after next All-Ukrainian census in 2020, according to the decree of the Cabinet of Ministers of Ukraine s of April 09, 2008 No. 581-p.s In spite of the current trends, which indicate low quality of life, there is not enough attention at the state level to regional development, including the areas affected by the ChNPP accident, especially in rural areas. In order to improve the demographic situation, it is necessary to reform the state policy on rural population, as well as to develop a strategy for demographic regional development of Ukraine, providing its sufficient financial support. Fundamental changes in state policy and in the development of the demographic strategy are also emphasized in the works of Chornyi \& Shevchuk (2013), Kuczabski \& Michalski (2013), Yeroshkina \& Derevyanko (2018). Chornyi \& Shevchuk (2013) point out that without a solution to this task, one might lose the opportunity of reproduction of the rural population, rural labor potential, and as a result, the chances of effective rural development in the future.

\section{Conclusion}

The low quality of life of the population in the radioactively contaminated areas in the Zhytomyr region was formed as a result of the prolonged unfavorable effect of the environmental factor. Negative trends are manifested in depopulation (the size of population decreased by $24.7 \%$ compared to 2002 ), high values of mortality and natural decline rates, aging, deterioration of medical state, as well as unsatisfactory living conditions of the population resident at Yemilchyno, Malyn, Ovruch, Korosten, Narodychi, Olevsk, Luhyny Ovruch raions of Zhytomyr region.

In order to improve the quality of life of the population of radioactively contaminated territories in the Zhytomyr region, it is necessary to reform the state policy, to provide financial support for their revival and creation of normal living and reproduction conditions for the population.

\section{References}

Bonatti, G., Ivaldi, E., Soliana, R. (2017). Quality of life in Italian cities: a temporal comparison between before the crisis and after. International Journal of Social Economics, 44(4), 560-574. doi: https://doi.org/10.1108/IJSE-10-2014-0214

Cecchini, M., Cividino, S., Turco, R., Salvati, L. (2019). Population Age Structure, Complex Socio-Demographic Systems and Resilience Potential: A Spatio-Temporal, Evenness-Based Approach. Sustainability, 11(7), 2050. doi: https://doi.org/10.3390/su11072050

Chornyi, R., Shevchuk, L. (2013). Demographic situation as a major factor to develop labour potential in rural areas. Skhid, 2(122), 67-70. doi: https://doi.org/10.21847/1728-9343.2013.2(122).13460

Ćwirlej-Sozańska, A. B., Sozański, B., Wiśniowska-Szurlej, A., Wilmowska-Pietruszyńska, A. (2018). Quality of life and related factors among older people living in rural areas in south-eastern Poland. Annals of Agricultural and Environmental Medicine, 25(3), 539545. doi: https://doi.org/10.26444/aaem/93847

Gobbens, R. J. J., van Assen, M. A. L. M. (2018). Associations of environmental factors with quality of life in older adults. The Gerontologist, 58(1), 101-110. doi: http://dx.doi.org/10.1093/geront/gnx051

Herasymchuk, L. O., Martenyuk, G. M., Valerko, R. A., Kravchuk, M. M. (2019). Demographic and onco-epidemiological situation in radioactive contaminated territory of Zhytomyr Oblast. Regulatory Mechanisms in Biosystems, 10(1), 32-38. doi: https://doi.org/10.15421/021905 
Huber, M. B., Felix, J., Vogelmann, M., Leidl, R. (2017). Health-Related Quality of Life of the General German Population in 2015: Results from the EQ-5D-5L. International journal of environmental research and public health, 14(4), 426. doi: $10.3390 /$ ijerph14040426

Johnson, K. M., Lichter, D. T. (2019). Rural Depopulation: Growth and Decline Processes over the Past Century. Rural Sociology, 84(1), 3-27. doi: https://doi.org/10.1111/ruso.12266

Keles, R. (2012). The Quality of Life and the Environment. Procedia - Social and Behavioral Sciences, 35, 23-32. doi: https://doi.org/10.1016/j.sbspro.2012.02.059

Kohler T., Elizbarashvili N., Meladze G., Svanadze D., Meessen H. (2017). The demogeographic crisis in Racha, Georgia: Depopulation in the central caucasus mountains," Mountain Research and Development, 37(4), 415-424. doi: https://doi.org/10.1659/MRD-JOURNAL-D-17-00064.1

Kuczabski, A., Michalski, T. (2013). The process of depopulation in the rural areas of Ukraine. Quaestiones Geographicae, 32(4), 81-90. doi: https://doi.org/10.2478/quageo-2013-0035

Li, S., Juhász-Horváth, L., Pedde, S., Pintér, L., Rounsevell, M. D. A., Harrison, P. A. (2017). Integrated modelling of urban spatial development under uncertain climate futures: A case study in Hungary. Environmental Modelling \& Software, 96, 251-264. doi: https://doi.org/10.1016/j.envsoft.2017.07.005

Lodhi, F. S., Montarezi, A., Nedjat, S., Mahmoodi, M., Farooq, U., Yaseri, M., Kasaeian, A., Holakouie-Naieni, K. (2019). Assessing the quality of life among Pakistani general population and their associated factors by using the World Health Organization's quality of life instrument (WHOQOL-BREF): a population based cross-sectional study. Health and Quality of life Outcomes, 17(1). doi: https://doi.org/10.1186/s12955-018-1065-x

Numbeo. (2019). Quality of Life Index for Country 2019 Mid-Year. URL: https://www.numbeo.com/quality-oflife/rankings by country.jsp

Pereira, D. S., Nogueira, D., Silva, C. B. (2015). Quality of life and the health status of elderly persons: a population-based study in the central sertão of Ceará. Revista Brasileira de Geriatria e Gerontologia, 18(4), 893-908. doi: https://dx.doi.org/10.1590/18099823.2015.14123

Romanchuk, L. D. (2015). Radioekolohichna otsinka formuvannia dozovoho navantazhennia u meshkantsiv silskykh terytorii Polissia Ukrainy : monohrafiia [Radioecological evaluation of the formation of the radiation burden with the residents of rural areas in Ukrainian Polissia : monograph]. Zhytomyr National Agroecological University, Zhytomyr (in Ukrainian).

Streimikiene, D. (2014). Comparative Assessment of Environmental Indicators of Quality of Life in Romania and Lithuania. Economics and Sociology, 7(1), 11-21. doi: 10.14254/2071-789X.2014/7-1/2

Theofilou, P. (2013). Quality of Life: Definition and Measurement. Europe's Journal of Psychology, 2013, Vol. 9(1), 150-162. doi: https://doi.org/10.5964/ejop.v9i1.337

Tiran, J. (2016). Measuring urban quality of life: case study of Ljubljana. Acta Geographica Slovenica, 56(1), 57-73. doi: https://doi.org/10.3986/ags.828

Ubarevičienè, R., van Ham, M. (2017). Population decline in Lithuania: who lives in declining regions and who leaves? Regional Studies, Regional Science, 4(1), 57-79. doi: 10.1080/21681376.2017.1313127

United Nations, Department of Economic and Social Affairs, Population Division (2019). World Population Prospects 2019: Highlights. URL: https://population.un.org/wpp/Publications/Files/WPP2019 Highlights.pdf

Vogelsang, E. M., Raymo, J. M. (2014). Local-Area Age Structure and Population Composition: Implications for Elderly Health in Japan. Journal of Aging and Health, 26(2), 155-177. doi: https://doi.org/10.1177/0898264313504456

Yeroshkina, T. V., Derevyanko, D. V. (2018). Medical-demographic problems of Ukraine and some ways of their overcoming. Medicni perspektivi, 23(3), 104-109. doi: http://doi.org/10.26641/2307-0404.2018.3.147966

\section{Citation:}

Romanchuk, L. D., Herasymchuk, L. O., Kovalyova, S. P., Kovalchuk, Yu. V., Lopatyuk, O. V. (2019). Quality of Life of the Population Resident at the Radioactively Contaminated Area in Zhytomyr Region. Ukrainian Journal of Ecology, 9(4), 476-483. 